\title{
Originals
}

\section{Persistent MHV (mouse hepatitis virus) infection reduces the incidence of diabetes mellitus in non-obese diabetic mice}

\author{
S. Wilberz ${ }^{1}$, H.J.Partke ${ }^{1}$, F. Dagnaes-Hansen ${ }^{2}$ and L. Herberg ${ }^{1}$ \\ ${ }^{1}$ Diabetes Forschungsinstitut der Universität Düsseldorf, FRG \\ ${ }^{2}$ Bomholtgard Breeding Research Centre, Ry, Denmark
}

Summary. The frequency of diabetes mellitus was compared in non-obese diabetic mice before and after inadvertent exposure of the colony to mouse hepatitis virus infection. Prior to exposure, diabetes prevalence and cumulative diabetes incidence in 7 -month-old mice was $65 \%$ and $25 \%$ in females and males, respectively. Diabetes incidence/quarter revealed a seasonal pattern with peaks in winter. After mouse hepatitis exposure, the diabetes incidence in the colony decreased and testing for mouse hepatitis antibody in blood samples revealed a persistent infection. In the offspring of mice delivered by caesarian section, the diabetic incidence increased sharply from a nadir of $36 \%$ to $95 \%$ and from $9 \%$ to $65 \%$ in females and males, respectively. In individual mice, diabetes resistance was strongly correlated to high titres of mouse hepatitis virus antibody. The results of this inadvertent viral infection demonstrate that a diabetes-susceptible genotype is strongly modulated by environmental factors. Investigators studying this diabetes model should strive for specific pathogen-free colony status and a high incidence of diabetes before attempting to investigate therapeutic modalities.

Key words: NOD mice, diabetes incidence, seasonality, mouse hepatitis virus infection.
Non-obese diabetic (NOD) mice spontaneously develop Type 1 (insulin-dependent) diabetes mellitus. Prior to weaning, lymphocytic aggregations occur in the periductular/perivascular areas of the pancreas. By four weeks of age, lymphocytes infiltrate into the islets and partially or even totally replace the pancreatic Beta cells [1]. Both $\mathrm{CD}-4^{+}$and $\mathrm{CD}-8^{+} \mathrm{T}$ cells were found to be essential for development of autoimmunity against pancreatic Beta cells $[2,5]$.

NOD mice are now maintained in various laboratories throughout the world. In most colonies there is a female preponderance of overt diabetes. Diabetes incidence, however, may vary considerably from one colony to another. This might be due, at least in part, to environmental factors such as subclinically persistent virus infections which are known to alter the immune system [6].

Therefore, we investigated whether the decrease in diabetes incidence in asymptomatic NOD mice maintained in a conventional system was caused by a persistent mouse hepatitis virus (MHV) infection.

\section{Materials and methods}

\section{Maintenance and breeding of NOD/HL mice}

In January 1985 a brother $\mathrm{x}$ sister breeding programme was started with 2 pairs of NOD mice from Clea (Osaka, Japan). Subline $1\left(\mathrm{~S}_{1}\right)$ was maintained until the 2nd quarter of 1989 (F9-F12) and sub- line $2\left(\mathrm{~S}_{2}\right)$ until the $3 \mathrm{rd}$ quarter of 1987 . The mice were conventionally kept with a $12: 12 \mathrm{~h}$ light:dark cycle, temperature was $24 \pm 2{ }^{\circ} \mathrm{C}$ and relative humidity was $65 \%$. Each subline was kept in a separate room and maintained by its own animal caretaker. The animal rooms were protected from the floor by double doors and permanent UV-light. Only the respective animal caretaker was allowed to enter in his room, however, all animal caretakers of our animal facilities met in the cleaning area where they cleaned the cages and cage racks of their animal room. On entering the animal rooms the animal caretakers wore special clothing, i. e., caps, face masks, rubber gloves, overalls, and rubber shoes. The cages were changed twice per week. The floor of the non-autoclaved cages was covered with autoclaved saw-dust. The food and non-acidified tap water were not autoclaved.

\section{Registration of the offspring and definition of diabetes}

At weaning, a total of 4150 offspring $\left(S_{1}+S_{2}\right)$ were recorded. Pups which died in the perinatal and early postnatal period were not listed. Weaned mice were checked daily for polyuria (wet cages). Blood samples from the tip of the tail were taken immediately after detection of polyuria. Mice with constant hyperglycaemia (blood glucose $>11 \mathrm{mmol} / \mathrm{l}$ ) were considered diabetic. The peak of diabetes onset was at day 140 , with only $6 \%$ of overt diabetes occurring after day 210 . Only those mice persistently normoglycaemic until day 210 were classified non-diabetic and were killed because of limited space. Normoglycaemic mice which died spontaneously, or were killed for experimental purposes before day 210 , or which were younger than 7 months at the end of the observation period (altogether 1406 mice with $48 \%$ and $52 \%$ females and males, respectively) were registered but not classified non-diabetic and not con- 
Table 1. Diabetes prevalence in NOD mice with regard to parental diabetes

\begin{tabular}{|c|c|c|c|c|c|}
\hline & $\mathrm{n} \times \mathrm{n}$ & $\mathrm{nxd}$ & $\mathrm{dxn}$ & $\mathrm{dxd}$ & total \\
\hline $\begin{array}{l}\text { Breeding pairs } \\
\text { mating type } \\
\text { no. }\end{array}$ & 108 & 29 & 211 & 108 & 456 \\
\hline $\begin{array}{l}\text { Offspring no. } \\
\text { registered }\end{array}$ & 838 & 323 & 2034 & 955 & 4150 \\
\hline classified & 338 & 199 & 1435 & 772 & 2744 \\
\hline $\begin{array}{l}\text { Pups/litter at } \\
\text { weaning }^{\mathrm{c}}\end{array}$ & 7.7 & 8.3 & 7.3 & 7.3 & 7.4 \\
\hline $\begin{array}{l}\mathrm{d} / \mathrm{d}+\mathrm{n}^{\mathrm{b}} \\
\text { females }\end{array}$ & $115 / 180$ & $67 / 113$ & $471 / 740$ & $284 / 412$ & $937 / 1445$ \\
\hline$\%^{d}$ & 63.9 & 59.3 & 63.6 & 68.9 & 64.8 \\
\hline males & $27 / 158$ & $18 / 86$ & $181 / 695$ & $97 / 360$ & $323 / 1299$ \\
\hline$\% d$ & 17.1 & 20.9 & 26.0 & 26.9 & 24.9 \\
\hline
\end{tabular}

a The first letter represents the mother, the second letter the father; $\mathrm{d}=$ diabetic; $\mathrm{n}=$ non-diabetic;

b diabetic/diabetic + non-diabetic;

${ }^{c}$ mating type and litter size are not associated: $\mathrm{Chi}^{2}=0.01, \mathrm{df}=1$, not significant;

d mating type and status of the offspring are not associated: $\mathrm{Chi}^{2}=5.08, \mathrm{df}=3$, not significant (females); $\mathrm{Chi}^{2}=7.18, \mathrm{df}=3$, not significant (males)

sidered for the evaluation of diabetes prevalence or diabetes incidence.

\section{Evaluation of diabetes prevalence and diabetes incidence}

Evaluation of diabetes prevalence was performed on 2744 classified female and male offspring. Diabetes incidence was tabulated on a quarterly basis in females and males.

\section{Detection of MHV (mouse hepatitis virus) infection}

In 1989, MHV infection was recorded in all mouse colonies of our animal facilities. The animals were free of respiratory-enteric orphan virus (Reo 3), pneumonia virus of mice (PVM), minute virus of mice (MVM), Theiler's encephalomyelitis virus (GD-VII), Sendai, and Ectromelia.

Freshly taken blood samples as well as samples taken at earlier time points for other purposes were stored at $-78^{\circ} \mathrm{C}$ and tested for the presence of MHV specific antibody as described below.

\section{Hysterectomy}

In November, 1988, hysterectomies were performed on pregnant MHV antibody positive female mice (F9 and F10) by one of the authors (F.D-H.). The offspring were nursed by C3H/Tif foster mothers, kept in a specific pathogen free SPF unit at the Bomholtgard Breeding Research Centre and found to be MHV antibody negative. Testing for MHV antibody was regularly done on the progeny. Diabetes incidence was evaluated in F12, F13 and F14.

\section{Determinations}

Blood glucose was determined enzymatically. The presence of specific antibodies was tested by ELISA (Bio Enzabead, Screen kit, Organon Teknika Corporation, Durham, NC, USA) using Easy
Reader 340 AT (SLT-Labinstruments, Gröding-Salzburg, Austria) and by indirect fluorescence. (We are grateful to Prof. Dr. V.Kraft for doing the indirect immunofluorescence tests.)

\section{Statistical analysis}

$\mathrm{Chi}^{2}$-analyses were performed on contingency tables. Linear regression analyses of the time course of diabetes incidence in females and males of either subline were performed by the least square method. Regression lines were calculated for the time between the 4th quarter of 1985 and the 1st quarter of 1989.

\section{Results}

The sex ratio of the mice weaned was 1:1. Litter size was not associated with the glycaemic state of the parents. Evaluation of 2744 offspring classified according to the parental status revealed no association between mating type and status of the offspring (Table 1).

Prior to MHV exposure diabetes prevalence was $65 \%$ and $25 \%$ in 7 -month-old females and males, respectively. Cumulative diabetes incidence at 7 months of age was also $65 \%$ and $25 \%$ in females and males, respectively.

At all times listed, diabetes incidence was higher in females when compared with males (Fig. 1, Table 2). Mean incidence was higher in mice of $S_{1}$ than in mice of $S_{2}(44 \%$ vs $24 \%$ in females, $14 \%$ vs $4 \%$ in males). Generally, diabetes incidence in $\mathrm{S}_{1}$ decreased from the beginning of 1986 until the 1st quarter of 1989 (Fig. 1) (Regression line $\mathrm{Y}=71.63-1.02 \mathrm{X}, r^{2}=0.44, t=3.06, p<0.05$; not shown).

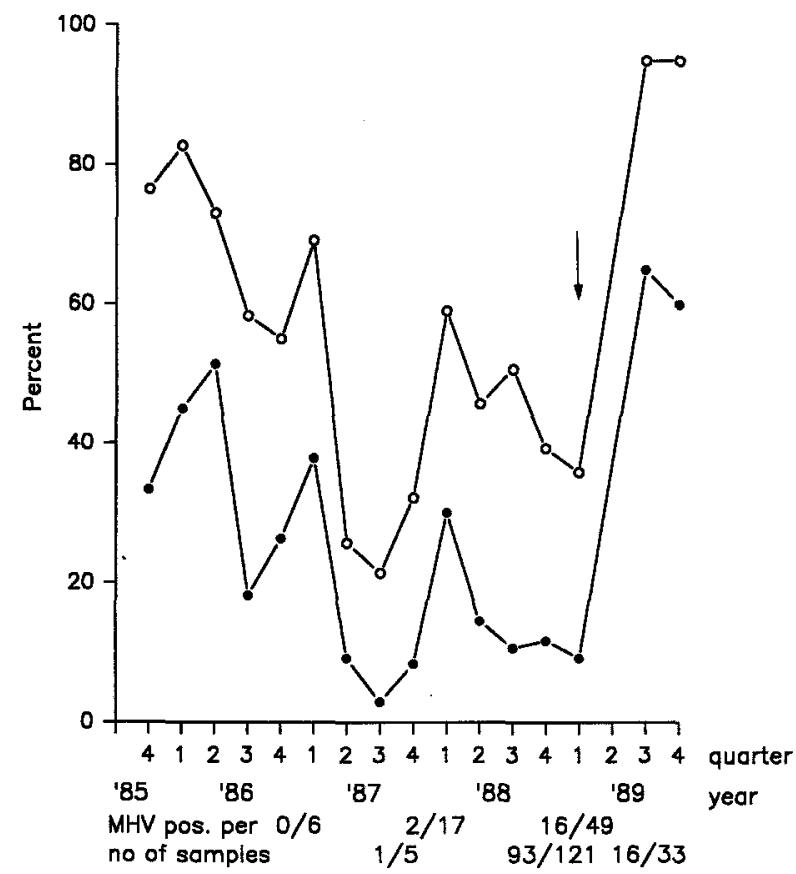

Fig.1. Diabetes incidence $(\%)$ in female $(\circ-0)$ and male $(\bullet-\bullet)$ NOD mice of subline 1 from the 4th quarter of 1985 until the 4th quarter of 1989. Arrow indicates the time of hysterectomy done on pregnant MHV positive female mice. The colony (except of the progeny of the hysterectomized mice) was extinguished between the $2 \mathrm{nd}$ and 3 rd quarter of 1989 when 16 of 33 randomly tested blood samples were MHV antibody positive 
Table 2. Diabetes incidence in two sublines of NOD mice before hysterectomy ${ }^{\mathrm{a}}$

\begin{tabular}{|c|c|c|c|c|c|c|}
\hline \multirow[t]{2}{*}{ Year } & \multirow[t]{2}{*}{ Quarter } & \multicolumn{3}{|l|}{$\mathrm{S}_{1}$} & \multicolumn{2}{|l|}{$\mathrm{S}_{2}$} \\
\hline & & Mice & Female & Male & Female & Male \\
\hline 1985 & $\begin{array}{l}4 \\
b\end{array}$ & & $\begin{array}{l}13 / 17 \\
76.5 \%\end{array}$ & $\begin{array}{c}5 / 15 \\
33.3 \%\end{array}$ & $\begin{array}{l}14 / 21 \\
66.7 \%\end{array}$ & $\begin{array}{c}3 / 29 \\
10.3 \%\end{array}$ \\
\hline 1986 & $\begin{array}{l}1 \\
2 \\
3 \\
4 \\
1-4^{c}\end{array}$ & & $\begin{array}{l}24 / 29 \\
19 / 26 \\
14 / 24 \\
11 / 20 \\
69.7 \%\end{array}$ & $\begin{array}{r}9 / 20 \\
19 / 37 \\
6 / 33 \\
10 / 38 \\
34.4 \%\end{array}$ & $\begin{array}{c}15 / 23 \\
21 / 27 \\
6 / 11 \\
1 / 7 \\
63.2 \%\end{array}$ & $\begin{array}{l}1 / 27 \\
3 / 27 \\
4 / 28 \\
0 / 27 \\
7.3 \%\end{array}$ \\
\hline 1987 & $\begin{array}{l}1 \\
2 \\
3 \\
4 \\
1-4^{c}\end{array}$ & & $\begin{array}{c}9 / 13 \\
9 / 37 \\
30 / 140 \\
67 / 208 \\
28.9 \%\end{array}$ & $\begin{array}{c}14 / 37 \\
8 / 87 \\
7 / 242 \\
25 / 299 \\
8.1 \%\end{array}$ & $\begin{array}{c}10 / 21 \\
6 / 39 \\
23 / 220 \\
\\
13.9 \%\end{array}$ & $\begin{array}{c}3 / 37 \\
1 / 74 \\
10 / 329 \\
\\
3.2 \%\end{array}$ \\
\hline 1988 & $\begin{array}{l}1 \\
2 \\
3 \\
4 \\
1-4^{c}\end{array}$ & & $\begin{array}{r}123 / 208 \\
54 / 118 \\
69 / 136 \\
59 / 150 \\
49.8 \%\end{array}$ & $\begin{array}{l}55 / 183 \\
17 / 117 \\
16 / 150 \\
23 / 196 \\
17.2 \%\end{array}$ & $\begin{array}{l}\text { d } 96 / 396 \\
\text { e } 24 \%\end{array}$ & $\begin{array}{c}25 / 578 \\
4 \%\end{array}$ \\
\hline 1989 & 1 & & $\begin{array}{l}52 / 145 \\
35.9\end{array}$ & $\begin{array}{c}15 / 163 \\
9.2\end{array}$ & & \\
\hline & Total & & $\begin{array}{l}\text { d553/1271 } \\
\text { e } 44 \%\end{array}$ & $\begin{array}{c}229 / 1617 \\
14 \%\end{array}$ & & \\
\hline
\end{tabular}

Incidence/quarter in absolute numbers, incidence/year in \%.

"See "Materials and methods";

b \% diabetes incidence within the quarter;

c \% diabetes incidence within the respective year;

d diabetes incidence;

e $\%$ diabetes incidence during the entire observation period

Diabetes incidence equally declined in $\mathrm{S}_{2}$. Regression line was $\mathrm{Y}=86.22-3.07 \mathrm{X}, r^{2}=0.70, t=3.78, p<0.05$ (not shown).

In offspring of both sexes of $\mathrm{S}_{1}$ diabetes incidence exhibited a seasonal pattern with peaks in winter (Fig. 1). A similar pattern was observed in $S_{2}$ (not shown). The low number of cycles tested however, precluded determination of statistical significance.

In the 1st quarter of 1989 specific MHV antibody was detected in freshly sampled blood of each subline maintained in a different room. Interestingly, retrospective testing for MHV antibody in stored samples established that the infection had been present since the 4 th quarter of 1986 in $S_{2}$. Concerning $S_{1}, 20 \%$ and $12 \%$ of the blood samples taken in $1987,77 \%$ and $35 \%$ of the samples harvested in 1988 and $49 \%$ of the blood samples taken in 1989 displayed MHV antibody (Fig. 1).

In the MHV-negative progeny of hysterectomized mice, diabetes incidence was $95 \%$ (19 of 20$)$ and $65 \%(13$ of 20) in females and males, respectively. In the following generation diabetes incidence was nearly identical: $95 \%$ (19 of 20$)$ and $60 \%$ (12 of 20) in female and male mice, respectively. At present (May 1990) the mice of F14 and F15 have not reached the age of 210 days.

Evaluation of 185 diabetic mice tested for MHV antibody revealed that $12 \%$ ( 6 of 50 ) and $6 \%(7$ of 40 ) of females and males, respectively, were diabetic and MHV positive whereas $59 \%$ (49 of 83 ) and $75 \%$ (9 of 12) of female and male mice, respectively, were diabetic and MHV negative $\left(\mathrm{Chi}^{2}=26.56, \mathrm{df}=1, p<0.001\right)$.

\section{Discussion}

We investigated diabetes frequency in NOD mice over a 4-year-period. When considering the total number of offspring, one should bear in mind that the true number might have been reduced by the number of pups which did not survive the weaning period. In pups of diabetic NOD mothers, enlarged kidneys, alterations in body weight, and a reduced pancreatic maturation rate were observed $[7,8]$. Nevertheless, we found that the number of pups/litter was similar in all mating types.

In our colony diabetes prevalence was $65 \%$ and $25 \%$ in females and males, respectively. It is very unlikely that the exclusion of about 1/3 (1406/4150) of registered offspring from this study has affected diabetes prevalence or diabetes incidence because the sex distribution in this cohort was quite similar. Nevertheless, the data on both diabetes prevalence and diabetes incidence must be considered as approximate. Diabetes frequency in our colony may be higher than depicted in the tables. Firstly, mice which were normoglycaemic on day 210 were grouped as non-diabetic even though they might have developed diabetes at a later date. Furthermore, mice which had died spontaneously or were killed for other experimental purposes while still being normoglycaemic might also have become diabetic in later life. Regardless of the potential diabetic offspring which were missed $(6 \%)$ diabetes prevalence in our colony corresponded well with that reported by other groups in NOD mice of 7 months of age maintained under SPF conditions $[9,10]$.

In offspring of 7 months of age we observed $65 \% \mathrm{cu}$ mulative diabetes incidence in females and $25 \%$ in males whereas in the original NOD colony of the Shionogi Aburahi Laboratories $80 \%$ and less than $20 \%$ were found in females and males, respectively [11-13]. Cumulative diabetes incidence in 24 or 26 -week-old female NOD mice varies widely from colony to colony, e.g., $40-45 \%[5,14]$ vs $80-85 \%[7,15]$.

The time course of diabetes incidence apparently revealed a seasonal pattern with peak onset in winter. So far, seasonality in animals has been described for dogs only [16]. As in NOD mice, this peak onset also occurs in dogs in winter. In both NOD mice and dogs, there is a clear female preponderance.

Overall diabetes incidence in our conventionally kept colony showed a clear downward trend with progression of time and generations. Therefore, as Tochino did [17], we concluded that diabetes incidence in NOD mice decreases with increasing generations.

The finding that diabetes incidence abruptly increased in offspring of NOD mice delivered by caesarian section confirmed pathogen involvement and specifically implicated the MHV infection in the overall decrease of diabetes incidence. This idea is supported by the fact that a low coincidence of diabetes is associated with MHV antibody in serum whereas a high diabetes incidence occurs in MHV antibody-free mice. Lowering of diabetes incidence by experimental viral infection has been reported in NOD mice as well as in BB rats [18-20]. In both species a variant of the lymphocytic choriomeningitis virus LCMV (ARM 53B clone 13) had been used. This variant 
is known to selectively suppress cytotoxic $\mathrm{T}$ lymphocytes, thereby favouring the progression from an acute to a chronic infection [21].

Recently, in spontaneously hypertensive rats (SHR) maintained under conventional conditions a high frequency of MHV antibody was found. In contrast to SHR under SPF conditions the conventionally kept SHR showed a depression of $T$ cell numbers and functions obvious from the reduced mitogenic reactivity of $\mathrm{T}$ cells and the reduced number of RFC (rosette forming cells) [22]. Although the mechanisms by which the persistent virus protects the animal from becoming diabetic is not fully understood [20] there is reason to believe that "the prevention of IDDM is most likely caused by virus-induced inactivation of potentially autoimmune reactive lymphocytes" [18].

In the light of the long-term MHV antibody persistance in our NOD colony and the progressive decrease of diabetes incidence followed by an abrupt increase after the mice had been cleaned from MHV infection, we conclude that the depression in diabetes incidence is due, at least in part, to a MHV-involved immunomodulation.

This study emphasizes the importance of a specific pathogen free environment for the maintenance of NOD mice when diabetes development is the desired phenotype. Diabetogenesis in the NOD mouse represents a remarkable example of interaction between heredity and environment to produce a complex disease.

Acknowledgements. We thank Dr. E.H. Leiter for critically reading the manuscript. The study was supported by the Deutsche Forschungsgemeinschaft (SFB 113), the Ministerium für Wissenschaft und Forschung des Landes Nordrhein-Westfalen and the Bundes- ministerium für Jugend, Familie, Frauen und Gesundheit.

\section{References}

1. Yui R, Fujita T (1988) Islet pathology in NOD mice. In: Shafrir E, Renold AE (eds) Frontiers in diabetes research. Lessons from animal diabetes II. Libbey, London Paris, pp 112-116

2. Makino S, Harada M, Kishimoto Y, Hayashi Y (1986) Absence of insulitis and overt diabetes in athymic nude mice with NOD genetic background. Exp Anim 35: 495-498

3. Koike T, Itoh Y, Ishii T, Ito I, Takabayashi K, Maruyama N, Tomioka H, Yoshida S (1987) Preventive effect of monoclonal antiL3T4 antibody on development of diabetes in NOD mice. Diabetes 36: 539-541

4. Wang Y, Hao L, Gill RG, Lafferty KJ (1987) Autoimmune diabetes in NOD mouse is L3T4 T-lymphocyte dependent. Diabetes 36: 535-538

5. Bendelac A, Carnaud C, Boitard C, Bach JF (1987) Syngeneic transfer of autoimmune diabetes from diabetic NOD mice to healthy neonates. Requirement for both $\mathrm{L} 3 \mathrm{~T} 4^{+}$and $\mathrm{Lyt}^{2+}$ T cells. J Exp Med 166: 823-832

6. Notkins AL, Mergenhagen SE, Howard RJ (1970) Effect of virus infections on the function of the immune system. Ann Rev Micro 24: $525-538$
7. Formby B, Schmid-Formby F, Iovanovic L, Peterson CM (1987) The offspring of the female diabetic "nonobese diabetic" (NOD) mouse are large for gestational age and have elevated pancreatic insulin content: a new animal model of human diabetic pregnancy. Proc Soc Exp Biol Med 184: 291-294

8. Azuma K (1985) The influence of maternal hyperglycemia on the fetal pancreas in the NOD mouse. J Tokyo Womens Med Coll 55: $456-462$

9. Makino S, Muroaka Y, Kishimoto Y, Hayashi Y (1985) Genetic analysis for insulitis in NOD mice. Exp Anim 34: 425-432

10. Wicker LS, Miller BJ, Coker LZ, McNally SE, Scott S, Mullen Y, Appel MC (1987) Genetic control of diabetes and insulitis in the nonobese diabetic (NOD) mouse. J Exp Med 165: 1639-1654

11. Makino S, Kunimoto K, Muraoka Y, Mizushima Y, Katagiri K, Tochino Y (1980) Breeding of a non-obese, diabetic strain of mice. Exp Anim 29: 1-13

12. Tochino Y (1986) The NOD mouse: similarities with and differences from BB rats. In: Diabetes 1985, Serrano-Rios M, Lefebvre PJ (eds) Elsevier Science Publishers BV, Amsterdam New York, pp 461-465

13. Harada M (1987) Immune disturbance and pathogenesis of nonobese diabetes-prone (NOD) mice. Exp Clin Endocrinol 89: 251-258

14. Nakajima H, Tochino Y, Fujino-Kurihara H, Yamada K, Gomi M, Tajima K, Kanaya T, Miyazaki A, Miyagawa J, Hanafusa T, Mashita K, Kono N, Moriwaki K, Nonaka K, Tarui S (1985) Decreased incidence of diabetes mellitus by monosodium glutamate in the non-obese diabetic (NOD) mouse. Res Commun Chem Pathol Pharmacol 50:251-257

15. Toyota T, Satoh J, Oya K, Shintani S, Okano T (1986) Streptococcal preparation (OK-432) inhibits development of type I diabetes in NOD mice. Diabetes 35: 496-499

16. Atkins CE, MacDonald MJ (1987) Canine diabetes mellitus has a seasonal incidence: implications relevant to human diabetes. Diabetes Res 5: 83-87

17. Tochino Y (1979) The spontaneously diabetic non-obese mouse with insulitis. In: Kosaka K (ed) Tonyobyogaku 1979. Shimdan to Chiryo Sha, Tokyo, pp 19-38

18. Oldstone MB (1988) Prevention of type I diabetes in nonobese diabetic mice by virus infection. Science 239:500-502

19. Dyrberg T, Schwimmbeck P, Oldstone M (1988) The incidence of diabetes in BB rats is decreased following acute LCMV infection. Adv Exp Med Biol 246: 397-402

20. Schwimmbeck PL, Dyrberg T, Oldstone MBA (1988) Abrogation of diabetes in BB rats by acute virus infection. Association of viral-lymphocyte interactions. J Immunol 140: 3394-3400

21. McChesney MB, Oldstone MBA (1987) Viruses perturb lymphocyte functions: selected principles characterizing virus-induced immunosuppression. Ann Rev Immunol 5: 279-304

22. Takeichi N, Hamada J, Takimoto M, Fujiwara K, Kobayashi H (1988) Depression of T cell-mediated immunity and enhancement of autoantibody production by natural infection with microorganisms in spontaneously hypertensive rats (SHR). Microbiol Immunol 32: 1235-1244

Received: 14 March 1990

and in revised form: 11 June 1990

Prof. Dr. L.Herberg

Diabetes Forschungsinstitut

der Universität

Auf'm Hennekamp 65

W-4000 Düsseldorf

FRG 